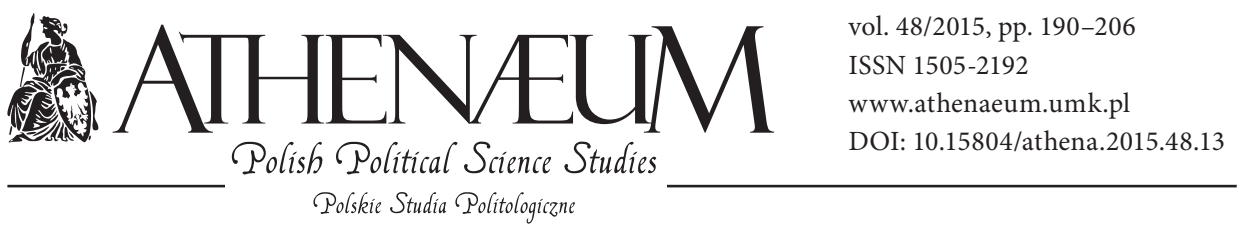

\title{
ETHNIC FRAGMENTATION AS CHALLENGE FOR POST-SOCIALIST GEORGIA
}

\author{
Zviad Abashidze*
}

\begin{abstract}
Article is giving the information on basic situation on civic integration in Georgia. Georgia, as multi-ethnic country, is facing the obvious problems with civic integration. The biggest part of the minorities (Azeris and Armenians) are ill-represented and performed in Georgian public. Therefore, Georgian statehood stands against the severe problems of inclusion of minorities in public space. There are number of models of minority accommodation from the international perspectives and experiences. Georgia should choose one of them. However, there is no standard model of such issue. In every case, each country stands vis a vis peculiarities and 100\% transplantation of any foreign model on local level is not relevant and adequate. Author, discussing the perspectives of civic integration, is arguing in favor of "integration" model against the "assimilation", "differentiation" and pure "multiculturalism". In case of "assimilation", the country will face the just claims from the minority side about losing their identities. If we adjust the model of "differentiation", that means to exclude the minorities from public life. Pure "multiculturalism" will stimulate the further fragmentation of the country. "Integration" model with some multicultural element seems more relevant and workable in Georgian realities.
\end{abstract}

\section{- KEYWORDS}

nation-building, ethnic minorities, civic integration

* Ivane Javalkhishvili Tbilisi State University, Georgia, Faulty of Social and Political Sciences. 
"Nation" and "ethnicity" have been the concepts of disagreement and ambiguous understanding for post-socialist Georgian polity. Two "ethnic conflicts" (Abkhazia, South Ossetia ${ }^{1}$ ), secessionism and territorial disintegration experienced by Georgia after the dissolution of USSR contributed in many respects for taboo-making on civic integration and ethnic accommodation. From the one side, we see the ethnic fragmentation and pluralism of the country, and from the other, the obvious need for resolving such fragmentation. Accordingly, the level of alienation, which bears ethno-religious character, in Georgian reality is quite high.

The problem is turning out clear when we start to speak about the civic integration of compact populated minorities such as Azeris and Armenians. For most of the Armenian and Azeri Minorities the command of official Georgian language is very poor. Unlikely, dispersed populated minorities are relatively integrated segments of the society. The command of dispersed populated minorities (especially in urban areas), the competence in official language is incomparable high. At the same time, their economic and socio-cultural performance in general Georgian public sphere have been much higher. The problems mostly are coming whenever we discuss the compact populated ones. Most of the compact populated Azeris and Armenians do not reflect themselves as organic part of the "Georgian Nation". Total amount of such big minorities in general percentage of total population is about $11 \%$ (Geostat). These large groups live along with ethnic Georgians as parallel society. Therefore, the strong ethnic stigmas, inherited especially from the soviet past, are quite strong and vivid.

In given article, based on descriptive methodology, we will discuss the experience of ethnic fragmentation of Georgia and strategies of civic integration undertaken by the political institutions. In many respects, inclusion of minorities in general public is not the home task of the country; it is kind of international obligation under the frame of international institutions as well. Therefore, "the making of Nation" is the principal task for present as well as for future successful democratic consolidation.

There are principal research questions that are going to meet answers by our article: a) what is the role of historical context of such story; b) how do the political institutions react on internal as well as on external challenges of

${ }^{1}$ Abkhazian and Ossetian cases are out of the article because of the present situation. These former autonomous regions of Georgia are recently out of control of Georgian state and recognized by few states (principally by Russian federation) as independent. 
ethnic diversity; c) what are the possible strategies of ethnic accommodation in Georgia.

Of course, the article does not pretend to fully clarify the minority issues, it stresses only on general key points of the problem. Therefore, the final answers of the story is located beyond the article.

\section{UNDERSTANDING OF ETHNIC DIFFERENTIATION IN CONTEMPORARY GEORGIA}

Public political discourse and the space of today's Georgia is distinguished with its multiplicity of ethnic categories and it is difficult to call it a vibrant political culture based on extensive citizen participation and on broad social and political consensus. The political culture of Georgia largely bears fragmented nature where the socio-political elements of the primordial and pre-modern type are not rare. Such reality does not really correspond to the processes and goals of the structuring of the idea of modern nation-state.

Of course, of creating such situation one can blame the political elites (including ethno-political elites), who are the main actors in determining the fate of the country. It is necessary to take into account the fact that the given elites operate in accordance with the specific historical heritage and the existing socio-political context, which, for its part, does not stimulate successful civic integration. Such circumstance has been broadly determined by the Soviet past and the experience of "nationality politics". Along with many problems, as the hallmark of the Soviet heritage can be named particularly strong ethnic stigmatization of society, overcoming of which was a difficult task for all multi-ethnic post-Soviet countries (Burbank, Cooper 2010; Suny 1989; Cornell 2001; Pipes 1954: 65; Brubaker 2005: 23-25; Hirsch 2005; Sakwa 1992: 25). Among these countries, having the problematic issues of ethnic and cultural character, Georgia remains one of the leading. Among all those stigmas, handed down to us by inheritance from the Soviet Union, comes out that the most complex one was the ethnic stigma. Overcoming the ethnic and cultural diversity especially hinder foreign policy factors and socio-economic context. In Georgia, the ethnic minorities have poor communication not only in the cultural and political, but also in economic terms. The national economic market has not been contributing to an intense relationship, competition and cooperation. Accordingly, it is not surprising that in most cases we actually face isolationism of ethnic minorities, 
and radical change for the better in near future is not expected. Despite the fact that in Georgia the legal framework is provided by many formal civil equality norms and the country is joined to all of the major international legislations which protect human rights, significant improvement has not been felt. We see that the formal legal equality norms alone cannot promote active civic activities and inter-ethnic integration (although without it at all it is unthinkable).

Civil integration prevents ethno-nationalist trends and myths, which have deep roots in the views of the majority of the population. These myths and perceptions play a crucial role in the realization of national self-determination and identity formation. Ethno-nationalist trends are strong not only among the ethnic Georgians, but also within the ethnic minority communities. The creation of ethno-nationalist tendencies has been contributed by several factors. These factors include historical past and legacy of the Soviet totalitarianism as well as the current socio-economic circumstances. In this regard, Soviet past is especially "distinguished", however, it has played a huge role, but we should not forget also about historical context until the Soviets. Probably rethinking of these two factors will help us to answer the questions: what was the base of origins of ethno-nationalist tendencies in Georgia and why is the integration of ethnic minorities so complicated? Of course, political elites have been contributing significantly to the situation, but as a rule, any political actor, intending to implement the particular political project, tries to acquire legitimacy for their actions. So, very often, these elites are slaves to such reality and, therefore, they are trying to strengthen their political projects with the ideas that are familiar and shared by the majority of citizens, adopted and approved by them.

\section{GEORGIA FROM THE HISTORICAL PERSPECTIVE}

\section{a) Medieval and modern narrations}

Social scientists generally agree that the process of construction of group's own identity is held under conditions of vis a vis relationships with "others". The image of "others" is the cornerstone of the strengthening of one's own identity. The approach is especially adequate to the construction of one's "national identity", when one intends to defend its "authenticity" from "others". Therefore, as it is justly accepted in social sciences, the differentiation between "we" and the "others" is crucial in process of understanding the spirit and sense of nationhood. 
It is broadly accepted by scholars as well as by public in Georgia that Georgians are one of the oldest cultural nations in the world, who through difficult historical developments used to try to defend the "civilized" space, from the very east boundaries, from barbarians. Such difficulties have been caused by Georgia's geopolitical situation, by means of borderline, i.e. intersection of European and Eastern civilizations. Therefore, the image of Georgians' centuries long struggle for independence and Christianity against the "uncivilized people" (Turks, Persians, Mongols, Arabs, Russians, etc.) broadly shaped their identity and sense of distinctiveness from the "others". Accordingly, to regard Georgians as a "new forming nation" is extremely "injustice" and is a form of "dis-knowledge of history". Moreover, if someone claims Georgians "Asiatic people" because of their ambiguous geographical location, it would be regarded as "disrespect" and "humiliation" of Georgians.

Theoretically, most of the contribution to understanding of "Georgianness" is expressed in $10^{\text {th }}$ century by the medieval paradigm of "Georgia" by the hagiographic author Giorgi Merchule: "Georgia is consisted of lands where the Christian mesas and every preach are exercised in Georgian" (Merchule 2002: 4).

In $11^{\text {th }}$ century, during the times the first centralized Georgian feudal state appeared, the modern name of Georgia in Georgian was acquired "SAQARTVELO".

The ancient Sumerian word "eri", the Georgian synonym of Latin "natio", historically has had a little bit different meaning than "natio". The Latin "natio" during the Middle Ages was the equal of the Greek "genes", and meant "origination or birth". Only in modern era it adopted the meaning of political community. During the Middle Ages, the "natio" usually was associated with language, students' community, or nobility. For example, when the chronicles spoke on a "gathering of French nation", they implied the gathering of French nobility and clergy (Habermas 2001: 87).

Firstly, in Georgian "eri” often was associated with language community (for instance, in first translations of the Bible), but primarily under it, the secular community was implied, regardless of ethnic or other origins of its members. During the mentioned "Golden Age", the "eri" became a term of common secular identity; regardless, it was nobility, peasants and etc. (excluding the King).

Such tradition remained in Georgia until the beginning of the $19^{\text {th }}$ century, the period of Russian domination.

Russian empire totally abolished the local Georgian traditions and shaped it as a province of the huge empire, and put under the process of russification. 
The notion "Georgia", as a political or cultural term, was completely cancelled from the vocabulary. The Independence Church of Georgia, along with statehood, was abolished in 1811 and subordinated to the Holy Synod of Russia. In general, Georgia became an organic part of Russian autocracy and bureaucratic government.

In this period, in Georgia so called Liberal nationalism was originated, the main representatives of which are the Georgian intellectuals from $60^{\mathrm{s}}$ of $19^{\text {th }}$ century, leaded by famous Georgian intellectual and public figure Ilia Chavchavadze. Ilia Chavchavadze's narration on "nation" became the cornerstone of modern understanding of "Georgia".

Unlike the medieval tradition, Ilia Chavchavadze tried to formulate the new view of Georgia and constructed a kind of new paradigm of Georgia: "Mamuli, Ena, Sartsmunoeba", "Fatherland, Language, Faith". According to the Leibnizian tradition, for Ilia "nation" became a movement from past through present to future, in other words, "nation" was an above-mentioned "trans-generational responsibility". Followingly, Ilia formulated the concept of "nation": "Nation is a community shaped by history with common will and contribution, the decline of the nation starts at the period when the nation forgets about its past" (Chavchavadze 1941; Jones 2005). For Ilia, as well as for other intellectuals from the given period, especially vital importance had a defense and revival of language and the rediscovery of Georgian history in order to construct the ground for future independence of Georgian state.

\section{b) First democratic Republic of 1918-1921}

Despite the very ancient history of Georgians, the first precedence of the modern nation-state is the period from 1918-1921, the small independence time. That was first experiment of implementation of "Nation-State" project in Georgian realities. Therefore, in such experience we can see some utopian democratic ideas as realistic and profitable ones that brought the Georgian Statehood of 1918-1921 to Western space in case of democratic state-building.

The Constitution of first democratic republic of 1921 declared the "nation" ("eri") as the only source of legitimacy, regardless the fact of country's ethnocultural diversity. The Constitution guaranteed civil and political liberties of the citizens including ethnic groups' rights, permitting them to use their language and other cultural ties publicly, including the Court and Parliament. Firstly, 
Georgian Republic became a unitary-decentralized state having two autonomous formations within the state borders (Abkhazia and Muslim populated part). But, as an irony of the history, the Constitution had been working only for four days, because of the Bolsheviks' invasion and abolishing the independence of the country (Matsaberidze 1996).

According to Constitution making process of 1921, ethnic minorities were granted the rights of usage of their native languages (along with official) in Courts, local authorities, and other public offices in case of necessity. Constitution stresses on rights of cultural autonomies of ethnic minorities in terms of education, printing of magazines, journals, etc. But Constitution excludes the rights of territorial autonomy except of Abkhazia. Despite such broad rights, minorities languages were not granted the rights of official languages along with Georgian. Public/Political sphere did not recognize the ethno-cultural diversity of the country at the public level. It was remained and recognized at the private level. Polity was admitted as community of equal citizens. The main experience of 1918-1921 in terms of civic accommodation was the model of "integration" and "assimilation"; "differentiation" and "multiculturalism" were rejected.

Generally, the project was a combination of historical experience, current issues, and inclination to implement the Western ideas on local ground. Georgian political elites were inclined to approach the Western space and expressed their devotion to such direction in every step of their policy.

\section{ETHNO-RELIGIOUS SETTLEMENT THROUGH HISTORY. AZERI AND ARMENIAN CASE}

Despite the fact that in the country for centuries different ethnic and religious groups (about 100) have lived side by side, they almost do not know (and if they do, badly so) the cultural values and achievements of each other. Given all this, we found it necessary in our study to make a brief historical review and to overview in what historical period and at which conditions the compact settlement of Armenians and Azerbaijanis has appeared in the country. The ethnic minorities are scattered almost all over the territories of Georgia, although ethnic minorities, which we consider within our study, live compactly mainly in two regions - in Samtskhe-Javakheti and Kvemo Kartli. Accordingly, based on the theme of our research, the subject of our interest is ethnic minorities who live in these areas - the Armenians and Azerbaijanis. 


\section{Armenians}

Of the 248,929 ethnic Armenians living in Georgia, most of the population lives in Samtskhe-Javakheti region. Ethnic Armenians make up 5.7\% of the total population (Geostat).

According to historical records, the settlement of Armenians in Georgia can be attributed to the ancient period. Although inhabited by Armenians compact regions where ethnic Armenians are almost absolute majority is more recent phenomenon and dates back to the $19^{\text {th }}$ century, after the conquest of Georgia by the Russian Empire.

The war that began in 1928 between Russia and the Ottoman Empire ended on September $14^{\text {th }}, 1929$ with a peace agreement in Adrianople. In this war, Turkey was defeated. On the basis of 13 Article of the peace treaty of Adrianople, Georgian Muslims living in Georgia got the right to resettlement in area of similar religion, Turkey, for 18 months.

On the liberated from Turkish yoke territories of Georgia, as a result of religious policy conducted by Tsarist Russia, most of the local Muslim Georgians were forced to leave their native territories and move to Turkey (though some Georgian Muslims still remained in the region) (Zurabashvili 1989: 34-35).

In parallel, under leadership of General Paskevich, of Kars, Ardahan, Baiyazeti and Erzerum tens of thousands of ethnic Armenians, of Christian religion, were resettled on the territories of Kvemo Kartli and Samtskhe-Javakheti. They inhabited exactly the territories devastated by the Georgian Muslims (Zurabashvili 1989: 37).

\section{Azeris}

According to the inventory of the population in 2002, in Georgia lives 284,761 Azerbaijanis (6.5\% of the whole population), and $78.9 \%$ of them live in the Kvemo Kartli region (Geostat).

Most Azeris migrated to this region in the $16^{\text {th }}$ and $17^{\text {th }}$ centuries, during the migration wave from the Ottoman Empire. Although according to historical sources, still in $11^{\text {th }}-12^{\text {th }}$ centuries there was a completion of indigenous with nomads in this region.

The most successful and consistent in the politics of settlement with foreign tribes was Shah Abbas I, the Iranian ruler of $16^{\text {th }}-17^{\text {th }}$ centuries. As a result of his 
policy, in some regions of Georgia and especially in Kvemo Kartli there appeared compact settlements of population of central and southern Iran (Zurabashvili 1989: 38-39). Communication between the already fragmented nomad tribes after them moving to the territory of Georgia was further weakened. Most of them assimilated with Azeris living closer. This bonding is facilitated also by the fact that they share a common language, similar social structure, some customs and, most importantly, religion. Over time, these ties have become stronger. And that is exactly the reason why the Muslim population of the Kvemo Kartli region perceives itself not as the Iranians or the Turks but as ethnic Azeris (Dundua, Abashidze 2009: 72-73).

\section{MINORITIES BASIC ATTITUDES TOWARDS PUBLIC SPHERE}

According to the empirical survey of $2009^{2}$ (the situation may have changed little bit, but the results are still valid), 72,5\% of Azeri respondents are occupied in non-public sector and their economical income is connected to private sphere. In comparison with Azeris, Armenians are relative higher involved in public sector. $23,5 \%$ of Muslim Georgians job occupation is public sector. In this case, the Orthodox Georgians are the leaders. Most of the questioned orthodox Georgians turned out involved in public sphere as the resource of economic income and job occupation (Dundua, Abashidze 2009).

All respondents determine their identity according to their ethnic affiliations. The only exception are Azeris, whose identity mostly is connected to their religious affiliations, that is an indicator of high influence of Muslim cultural traditions in given community. Therefore, we can conclude that the principal base of "national identity" among the citizens of Georgia goes to ethnic lines and affiliations.

On the question, "What does it mean to be a Citizen of Georgia", with answer "Living in Motherland" (90,7\%) Muslim Georgians occupy the leading positions. Such answers have also big place in Azeris' and in Armenians' answers. 83,6\% of Azeris and 87,3\% of Armenians regard Georgia as Motherland. That means that all questioned ethnic groups consider Georgia as Motherland and principal place of living affiliation. Azeris are mostly weakly involved in public-political sphere.

\footnotetext{
2 Author was personally engaged in the survey.
} 
Only $0,7 \%$ of them regard themselves as active participants of civic-public living sphere (Dundua, Abashidze 2009).

The case of marriage issues varies according to ethnic communities. Ethnic Georgians (as Orthodox as Muslims) prefer marriage with their ethnic co-brothers. The same situation is fixed with Azeris. Only big percentage of Armenians are indifferent in marriage issues and do not worry very much about their future fiancées' ethnic affiliations.

In inter-ethnic communication issues, ethnic minorities are leaders in comparison with ethnic Georgians. $64,4 \%$ of Azeris and 86,4\% of Armenians are connected in everyday life with people of different ethnic affiliations. Only 37,2\% of Georgians regard themselves as being connected in everyday life with citizens of non-Georgian ethnic originations (Dundua, Abashidze 2009).

In information getting issues, most of the respondents from ethnic minorities' side are getting the information from the informal way and their trust to informal network is relatively high in comparison with official information sources. Except of Azeris, for most of the respondents the source of information is the information that are coming from the kins and friends. Among the media sources, for most of the population TV broadcastings are the principal source of information. As for the journals and newspapers, because of the lack of knowledge of official language only small number of Azeris use them as the source of information.

Most of the respondents from the ethnic minorities declare that they do not use the official language as work language. The reason of such answers from our point of view is that most of the polled population from the ethnic minorities side do not work in public offices and that is why the knowledge of Georgian as work language do not have big importance.

Most of the respondents have positive attitudes toward the official state symbols (flag, anthem, coats of arms). Surprisingly, only 83,2\% of Georgians are positively minded to such symbols with strong Christian background, while 92\% of Armenians and 94,3\% of Azeris have absolutely positive attitudes to the symbols. It is possible that ethnic minorities do not express their true attitudes toward symbols. Otherwise, it is not clear why the Muslim Azeris have positive attitudes toward Christian symbols, while orthodox Georgians often express their negative perception of the state symbols (Dundua, Abashidze 2009).

Among the respondents from the ethnic minorities side, on the question of character of relationships with other ethnic groups, the neighborhood type of relationships are prevailed (70\%). Family type of relationships are relatively high 
among the Armenians (5,9\%). Respondents declare that, in most cases, their ethnic or religious affiliations are not the obstacle to be promoted in civic-public sphere, if the level of knowledge of official language is appropriate (Dundua, Abashidze 2009).

In case of marriage and preferences of elections, ethnic Georgians mostly pay attention to ethnic or religious affiliations. $56,4 \%$ of them think that ethnic/ religious attachments of the future marriage/political candidate is very important. Ethnic minorities did not express their special interest to candidates ethnic/ religious affiliations during elections.

Georgian is the mother tongue only for ethnic Georgians. Most of the representatives of ethnic minorities are homogeneous in this case and regard their ethnic tongue as mother. Only for few exceptions of Armenians the Georgian $(4,5 \%)$ and the Russian language (10\%) is the principal tongue of usage (Dundua, Abashidze 2009).

\section{MINORITIES FROM THE INTERNATIONAL PERSPECTIVE}

On May $2^{\text {nd }}, 2014$, Georgian parliament adopted the anti-discrimination law that highlighted the needs of vanishing of all kind of discrimination and among them - vanishing of ethnic discrimination (Civil.ge 2014a). Previous Georgian juridical codifications (Constitution among them) more or less used to regulate the mentioned issue, but adoption of the law was a prelude to signing the Association Agreement with the EU. Therefore, the anti-discrimination law was not the pure intention of Georgian lawmakers. It was a clear outcome of international (in our case, European) influence. After adoption of the Law, on June $27^{\text {th }}$, Georgia signed the Agreement (Civil.ge 2014b) and on July 18 ${ }^{\text {th }}$, Georgian Parliament ratified it (Civil.ge 2014c), which brought Georgia much closer to the EU space. The Agreement highlights the importance of defense of minorities and stands for peaceful resolution of conflicts, but the minority case is not the separate part of the Agreement and is strongly connected with Human Rights issues (MFA 2014).

Mentioned regulations influence directly or indirectly Georgian realities of ethnic minorities. CoE regulations are more crucial among them. Georgia is practically a part of any international agreement on Human Rights. However, Georgia still has the modest position on signing some of the European regulations and therefore, there is no full implementation of them. 
For instance, the document such as the European Charter of Regional and Minority Languages has been still outside of official recognition of Georgia, however, after the membership in $\mathrm{CoE}$, Georgia took the obligation to sign and implement it. The case of such rejection is clear. If Georgia signs the Charter, theoretically, it will recognize 19 of local/minority languages officially and take special concern of their defense. In that case, Svan and Megrelian languages are most debatable among Georgian public and academics as well. According to many scientists, Svan and Megrelian languages have been formed as languages without official alphabet and recognition. For many scholars, Svan and Megrelian are only idiomatic branches of common Georgian language and their separate recognition is the obvious threat for Georgian identity and Georgian statehood in general (Putkaradze 2012). At the same time, along with such "languages", Georgia will possibly have to formalize the languages of all minorities - that, from the Georgian perspective, seems very alarming for territorial integrity. For instance, Armenian and Azerbaijani languages are not under any threat, because of the existence of Nation-State on their historical homelands with such officially recognized languages. Georgian side avoids the formalization of the rest of the languages except Georgian (exception is the recognition of Abkhazian language along with Georgian as official on Abkhazian territory), because of fear of possible further dissolution and disintegration. If we look at Georgia's post-communist story, such fear appears very legitimate. In regions where the minorities have the compact settlements (Armenians in Javakheti and Azeris in Kvemo Kartly, where they are ethnically in majority), the ethno-separatist trends are not totally vanished. Therefore, Georgian side argues on its moral arguments on such position and claims for maintenance of statehood. Many political scientists justly argue that for the Central-East European space the minority issues have not been the case of strategies of tolerance and integration. Because of unstable historical developments, late modernization and nation-state formation, the matters of minorities are a part of broader concept of security. Because of "security" dilemma, for many Central-East Europeans' understanding, minorities from given states are often linked with the enemies of their statehood and work according to their instructions (Rex, Sigh 2003: 3-4). Such situation expresses well Georgia's relationships with the Charter.

In spite of such situation, Georgia is a part of the European framework convention of minorities and actively implements its norms. The most obvious expression of such process is the adoption of "The National Conception of Tolerance of Civic Integration" by Georgian Government in 2008. The Conception is 
the main normative base for further state strategy of civic integration and ethnic accommodation. Georgian Government has the obligation to report on cases of minorities before the $\mathrm{CoE}$ and other European institutions. According to such reports, there is significant progress in such issues, along with the obstacles. Such obstacles, according to the reports, are not the outcome of deliberate discrimination and oppression. Mainly such obstacles are common for countries with socio-economic problems and still weak democratic political institutions.

Georgia still has not fully filled the obligations undertaken before the $\mathrm{CoE}$ prior to the membership, connected with so called "Meskhetian-Turks" repatriation. However, the case is a part of official agenda of every Georgian government, without concrete deadlines and schedules (ECMI 2011: 120-125).

After the "Rose Revolution" of 2003, many changes occurred in political institutions including the regulatory structures of minorities. Actually, there is no single political structure and centralized competences on minority, there are several of them. The main coordinator of such structures is the Ministry of Reconciliation and Civic Equality, which occupies the main competences.

From the legislation branch, the Parliamentary Committee of Human Rights and Civic Integration is the core structural unit. There are several Committees indirectly involved in such issues as well, but they are dependent on the central one. National Minorities Council in Public Defenders office is the additional structural unit on such issue (ECMI 2011: 120-125).

In many respects, the competence among such structural units are mixed and there are no clear demarcation lines. Many international organizations require to create centralized political-structural units for better and effective policies, but in reality, the existence of such type of unit is absent, with no clear future (BTTK 2008).

\section{PERSPECTIVES OF CIVIC INTEGRATION}

It can be said that in post-communist Georgia state is unable to guarantee its two fundamental functions: provision territorial sovereignty and social contract. That is why Georgian statehood was unable to consolidate and integrate fragmented social space and transfer it into the vibrant civic space. Ethnic minorities, in fact, are mostly isolated from public-political sphere and exist under strong internal ethnic hierarchy. Actually, the situation is not satisfactory from the perspectives of civic accommodation. Ethnic minorities live along with Georgian dominant 
group, but the impulses of cohabitation and cooperation are quite low. In fact, we have two parallel societies. Of course, there is some degree of cooperation between ethnic majority and minorities, but mostly such relationships are based on vertical lines of mobility and do not stimulate horizontal lines of communications. Ethnic minorities are ill-equipped with the instruments (low level of knowledge of official language, low level of information on public life, low level in creation of public goods, etc.) of successful public-political integration, that, in turn, do not give them chances to convert to active citizens of Georgia. The reality has been more intensified by the compact and rural housing of ethnic minorities with very low level of urbanization. Among the ethnic minorities who populate the urban areas the level of civic integration and sense of political loyalty to Georgian statehood is much higher. Rural populated ethnic minorities, thanks to low level of institutionalization and weak economic performance of the Country in general, mostly are separated from the core pivot of country's development. The fact has been adequately reflected in minorities' everyday life. Moreover, the minorities are populated along the borders with their ethnic motherland that gives them the additional stimulus to feel more affiliated with their ethnic cobrothers than with their political motherland. The level of loyalty of minorities to the countries of their ethnic origins is much higher. Unfortunately, political motherland is unable to guarantee the strong sense of civic/political loyalty and identity among their non-Georgian citizens.

As seen above, the formation of "nation" as a community of common solidarity grounded on civic affiliations is a one of the primary task of post-Soviet Georgia, where the "national" loyalty and "state loyalty" are contradictory phenomena, because of strong ethnic categories' presence in politics and public discourse.

But the problem is what kind of strategy the state has to adopt officially for successful nation-building: "assimilation", "differentiation", or "integration"? What kind of strategy would work better in order to construct strong "national" boundaries? We wrote on spirits of "assimilation" and "differentiation" strategies, but wrote nothing on "integration" strategy, which, from our point of view, is more workable and realistic than the other two. "Integration" is a strategy that tries to bring together under one political loyalty different segments of the society on one side, and to guarantee the minority culture existence and protection on another.

Therefore, from our point of view, firstly, Georgia has to formulate the new governmental strategies to provide the unity of the country under the civil- 
ity and civil categories. Without it, it is really hard to imagine how Georgia will manage to become a consolidated democracy. Such unity surely must be completed with new institutional arrangements, which would be providers of free political participation. Without free participation, strong democratic institutional arrangements and network free market economy, which provide the intensive inter-communication among the different groups, it seems unrealistic to make Georgia strong, modern nation-state.

\section{CONCLUSION}

In conclusion, it is obvious that the ethnic diversity for Georgia is not only an internal challenge, but it bears international character as well. For proper understanding of contemporary Georgian ethnic differentiation one must see that "history" (medieval, soviet, etc.) plays an enormous role in understanding the concepts of "ethnicity" and "nation". Therefore, there are several factors, which can work for proper civic integration issue.

Accordingly, we can indicate several factors that stimulate the ethnoconfessional alienation process:

a) Low level of modernization and urbanization causes social closeness and too low level of social mobility.

b) Cultural and informative alienation. Because of closeness of cultural developments, one ethnic group is indifferent to its neighbor group's cultural achievements, and vice versa.

c) Factual economic alienation and primacy of manorial economy over the modern free market and goods exchange.

d) Civic alienation. Weak civic institutional network does not guarantee the vibrant cooperation on non-governmental level and, accordingly, articulation of private interests.

e) Alienation on political-institutional level. Weak democratic institution does not guarantee the conversion of ethnic groups into one strong political community.

From our point of view, Georgian State should take several steps to reduce the sense of the ethnic identity and stimulate the civic one among Georgian dominant ethnic group, as well as among ethnic minorities:

1) Creation of stable democratic environment is the primary task and base for further successful institutional development. 
2) Improvement of the local self-government, in order to stimulate the development of political processes on local level and to strengthen the interests to be included into civic-political space.

3) Educational system should guarantee the relevant knowledge of official language among ethnic minorities, and especially among their youth.

4) Promotion of inter-ethnic cultural projects to encourage the ethnic groups to intercultural exchanges.

5) Strengthening the process of urbanization, in order to reduce the primordial affiliations of minorities and gradually replace them with relatively modern ones.

\section{REFERENCES:}

Brubaker R. (2005). Nationalism Reframed. Nationhood and the National Question in the New Europe. Cambridge: Harvard University Press.

BTTK. Ethnic Minorities Program. (2008). Policy Analysis of Civil Integration of Ethnic Minorities in Georgia. [online] www.btkk.ge; [accessed 20.05.2015].

Burbank J., Cooper F. (2010). Empires in World History. Princeton: Princeton University Press.

Civil.ge. (2014a). Anti-Discrimination Bill Approved. [online] http://civil.ge/geo/article. php?id=28143; [accessed 20.05.2015].

Civil.ge. (2014b). US welcomes EU Association Agreements with Georgia, Moldova and Ukraine. [online] http://civil.ge/geo/article.php?id=28408; [accessed 20.05.2015].

Civil.ge (2014c). EU Association Agreement Ratified. [online] http://civil.ge/geo/article. php?id=28505; [accessed 20.05.2015].

Cornell S.E. (2001). Autonomy and Conflict: Ethnoterritoriality and Separatism in the South Caucasus - Cases in Georgia. Uppsala: Blackwell Publisher.

Dundua S., Abashidze Z. (2009). Ethnic and Religious Identities and Civic Integration Issues in Georgia. Tbilisi: Intelekti.

ECMI. The European Centre for Minority Issues. (2011). Minority Issues Mainstreaming in South Caucasus: A Practical Guide. [online] http://www.ecmi.de/uploads/tx_ lfpubdb/Minority_Issues_South_Caucasus_fulltext.pdf; [accessed 20.05.2015].

Geostat. [online] www.geostat.ge; [accessed 10.06.2015].

Habermas J. (2001). Vovlechenie Drugogo. Sankt Petersburg.

Hirsch F. (2005). Empire of Nations. Ethnographic Knowledge and the Making of the Soviet Union. Ithaca: Cornell University Press.

Matsaberidze M. (1996). The Political Conception of the 1921 Constitution of Georgia. Tbilisi: Society “Tsodna”.

Merchule G. (2002). Life and Citizenship of Our Father Grigol of Khatsta. Tbilisi. 
MFA. Ministry of Foreign Affairs. (2014). Association Agreement between EU, EURATOM Member States and Georgia. [online]. http://mfa.gov.ge/index.php?lang $\mathrm{id}=\mathrm{GEO} \& \mathrm{sec}$ id=30\&info_id=17011; [accessed 20.05.2015].

Pipes R. (1954). The Formation of the Soviet Union: Communism and Nationalism, 1917-1923. Cambridge: Harvard University Press.

Putkaradze T. (2012). Charter of Languages and Contemporary Language Situation in Georgia. [online] http://www.putkaradze.ge/cigni\%20dasrulebuli/links/2.3.2.html; [accessed 20.05.2015].

Rex J., Sigh G. (2003). Multiculturalism and Political Integration in the Modern Nation State - Thematic Introduction. "Journal on Multicultural Societies" Vol. 5, No. 1. [online] www.iunesco.org/shs/ijms; [accessed 20.05.2015].

Sakwa R. (1992). Soviet Politics, an Introduction to Georgia. [in:] History and Comparison in the Study of the USSR. A.J. Motyl (ed.). New York: Columbia University Press.

Suny R. (1989). State-Building and Nation-Making. The Evolution of Ethnonationalism under Soviet Rule. London: Routledge.

Zurabashvili L. (1989). Traditions of Interethnic Relations in Georgia. Tbilisi: Matcniereba. 